\title{
Performance Evaluation of Polyamide Reverse Osmosis Membrane for Removal of Contaminants in Ground Water Collected from Chandrapur District
}

\author{
Vidyadhar V. Gedam ${ }^{1 *}$, Jitendra L. Patil², Srimanth Kagne ${ }^{1}$, Rajkumar S. Sirsam² and Pawankumar Labhasetwar ${ }^{1}$
}

${ }^{1}$ National Environmental Engineering Research Institute, Nagpur- 440020, Maharashtra, India

${ }^{2}$ Department of Chemical Technology, North Maharashtra University, Jalgaon- 425001, Maharashtra, India

\begin{abstract}
This paper examines the influence of different operating parameters such as pressure, temperature, $\mathrm{pH}$ on the performance of polyamide reverse osmosis membrane. Varying these parameters, intensive trials were undertaken to study the performance of polyamide Reverse Osmosis (RO) membrane. Water samples for experiment were collected from Moradgaon village of Chandrapur district having high concentrations of fluoride, Total dissolved solids (TDS), sulphate and iron. Results indicate that polyamide reverse osmosis membrane can successfully remove 95 to $98 \%$ of fluoride, TDS, sulphate, iron and other ground water contaminants under optimized conditions. Different parameters such as $\mathrm{pH}$, pressure and temperature affects $\mathrm{RO}$ membrane efficiency. Thus, proper control of these factors is essential for successful operation and maintenance. RO Membrane generates huge quantity of reject water (i.e.65\% -75\%), which was further passed through RO membrane to study its reuse potential. The results showed that water received from RO membrane after recycling of membrane reject is within the permissible limits of drinking water as prescribed by Bureau of Indian Standards (BIS).
\end{abstract}

Keywords: Drinking water; Ground water; Polyamide membrane; Operating parameters; Reverse osmosis (RO)

\section{Introduction}

India has been well endowed with large freshwater reserves, but increasing population and over-exploitation of surface and groundwater over the past few decades has resulted in water scarcity in most regions. Existing freshwater reserves are being polluted due to inadequate control and unsafe system in view of urbanization, over-exploitation and natural activity. It was estimated that around 37.7 million Indians are affected by waterborne diseases annually, 1.5 million children are estimated to die of diarrhea alone and 73 million working days are lost due to waterborne disease each year [1]. The resulting economic burden is estimated at $\$ 600$ million a year [2]. The problems of chemical contamination are also prevalent in India with $1,95,813$ habitations in the country are affected by poor water quality [3]. The poor quality of raw water sources warrants the application of stringent treatment technologies and proper monitoring to ensure supply of safe drinking water. In India ground water is considered as a safe source of drinking water which is being utilized intensively for drinking, irrigation and industrial purposes. However, due to rapid growth of population, urbanization, industrialization and agricultural activities, Indian ground water resources are under constant stress. There is growing concern on the deterioration of ground water quality due to geogenic and anthropogenic activities. The main ground water quality problems in India are inland salinity, coastal salinity, fluoride, arsenic, iron and nitrate [4].

Many technologies are developed for removal of these contaminants which includes, filtration, chemical treatment, advanced oxidation and membrane separation process. This paper investigates the influence of different operating parameters such as pressure, temperature and $\mathrm{pH}$ on performance of polyamide reverse osmosis membrane for removal of fluoride, TDS, sulphate, iron and other ground water contaminants. In addition, its recycling potential for reject water which was generated during above experiments is also studied in detail.

\section{Materials and Methods}

The experiment was performed using a thin film composite polyamide spiral wound RO membrane. The module consisted of a Filmtec Spiral wound with composite polyamide membrane module (model no. TW30-1812-75) with effective area of $0.1054 \mathrm{~m}^{2}$, module length $300 \mathrm{~mm}$ and diameter of $40 \mathrm{~mm}$.

A detailed RO membrane module experimental setup is shown in Figure 1. Ground water sample was collected from a hand pump at Moradgaon village, Chandrapur - Maharashtra. The ground water sample had high concentration of TDS, fluoride, chloride, hardness, alkalinity, iron, sulphate and turbidity than the permissible limits as per BIS: 10500. The physico-chemical analysis of water sample collected from Moradgaon village is shown in Table 1.

RO membrane module was operated under various operating parameters such as feed water temperature, pressure and $\mathrm{pH}$. The effect of different operating parameters on performance RO membrane was studied by varying one parameter at a time and keeping others constant. Table 2 shows the operating variables during reverse osmosis.

\section{Recycling potential of membrane reject water}

During reverse osmosis process 50 to $65 \%$ of membrane reject

*Corresponding author: Vidyadhar V. Gedam, National Environmental Engineering Research Institute, Nagpur- 440020, Maharashtra, India, E-mail: gedmvidyadhar@gmail.com

Received June 11, 2012; Accepted August 28, 2012; Published September 04, 2012

Citation: Gedam VV, Patil JL, Kagne S, Sirsam RS, Labhasetwar P (2012) Performance Evaluation of Polyamide Reverse Osmosis Membrane for Removal of Contaminants in Ground Water Collected from Chandrapur District. J Memb Sci Technol 2:117. doi:10.4172/2155-9589.1000117

Copyright: (c) 2012 Gedam VV, et al. This is an open-access article distributed under the terms of the Creative Commons Attribution License, which permits unrestricted use, distribution, and reproduction in any medium, provided the original author and source are credited. 
Citation: Gedam VV, Patil JL, Kagne S, Sirsam RS, Labhasetwar P (2012) Performance Evaluation of Polyamide Reverse Osmosis Membrane for Removal of Contaminants in Ground Water Collected from Chandrapur District. J Memb Sci Technol 2:117. doi:10.4172/2155-9589.1000117

Page 2 of 5

water is generated [5]. To reutilize such an enormous amount of reject water and to test membrane recycling performance, it was recycled back through RO membrane. During experiment, reject of first run was used as feed for second run and reject of second run was used as feed for third run. This process was continued till RO permeate showed concentration of fluoride, TDS and other contaminants more than the permissible limits as prescribed by [6].

\section{Results and Discussion}

\section{Effect of feed water temperature}

Temperature is one of the important parameter which affects the performance of $\mathrm{RO}$ membrane [7]. The effect of varying temperature keeping other parameters constant on performance of RO membrane is shown in graphs.

It can be observed from Figure 2-6 that as feed water temperature increases from 18 to $40^{\circ} \mathrm{C}$, the permeate salinity (TDS) increases from 148 to $288 \mathrm{ppm}$, permeate flux increased from 1.4 to $2.3\left(1 / \mathrm{m}^{2} . \mathrm{min}\right)$, fluoride concentration increased from 0.02 to $0.2 \mathrm{ppm}$ and \% recovery increased from 21.83 to $35.93 \%$. But the \% salt rejection decreases from 92.43 to 85.23 . Increase in TDS, permeate flow, flux, fluoride concentration and \% recovery with decrease in \% salt rejection is observed because, as temperature increases viscosity decreases and water permeation rate through membrane increases. As temperature increased solubility of solute increased and higher diffusion rate of solute through the membrane is possible [8].

\section{Effect of feed water pressure}

Pressure is one of the most important operational parameter

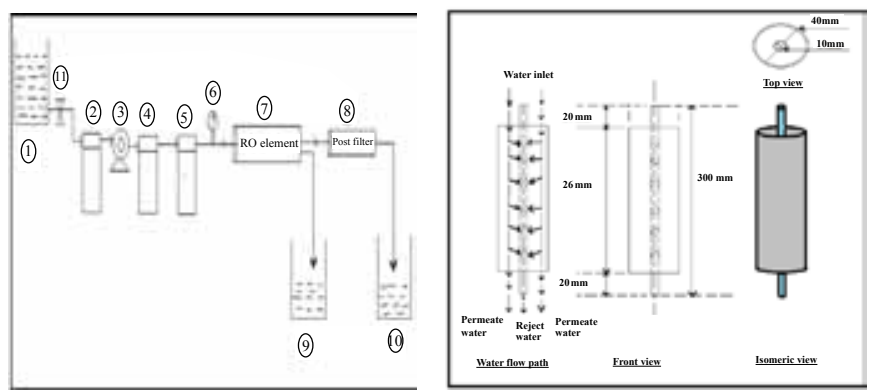

Figure 1: Experimental set up, different views and water flow path for RO membrane module.

\begin{tabular}{ll}
\hline Parameters & Water Sample \\
\hline Temperature ${ }^{\circ} \mathrm{C}$ & 22.9 \\
\hline $\mathrm{pH}$ & 9.2 \\
\hline $\mathrm{EC}(\mu \mathrm{s} / \mathrm{cm})$ & 3250 \\
\hline TDS $(\mathrm{ppm})$ & 1950 \\
\hline Chloride $(\mathrm{ppm})$ & 815.35 \\
\hline Fluoride $(\mathrm{ppm})$ & 2.13 \\
\hline Hardness $(\mathrm{ppm})$ & 140 \\
\hline Calcium $(\mathrm{ppm})$ & 120 \\
\hline Magnesium $(\mathrm{ppm})$ & 20 \\
\hline Alkalinity $(\mathrm{ppm})$ & 28 \\
\hline Iron $(\mathrm{ppm})$ & 0.88 \\
\hline Sulphate $(\mathrm{ppm})$ & 128.75 \\
\hline Turbidity $(\mathrm{NTU})$ & 3.26 \\
\hline Nitrate $(\mathrm{ppm})$ & $\mathrm{ND}$
\end{tabular}

Table1: Physico-chemical analysis of water sample collected from Moradgaon village.

\begin{tabular}{llll}
\hline \multirow{2}{*}{ Experimental Parameters } & \multicolumn{3}{c}{ Operating parameters } \\
\cline { 2 - 4 } & $\mathrm{T}\left({ }^{\circ} \mathrm{C}\right)$ & $\mathrm{P}(\mathrm{psi})$ & $\mathrm{pH}$ \\
\hline Feed temp. $(\mathrm{T})$ & Varied & 80 & 8.35 \\
\hline Pressure (P) & 30 & Varied & 8.35 \\
\hline Conc.(TDS) & 23 & 80 & 8.35 \\
\hline $\mathrm{pH}$ & 25 & 80 & Varied \\
\hline Flow rate (F) & 25 & 80 & 8.00 \\
\hline
\end{tabular}

Table 2: Operating variables of RO Membrane system.

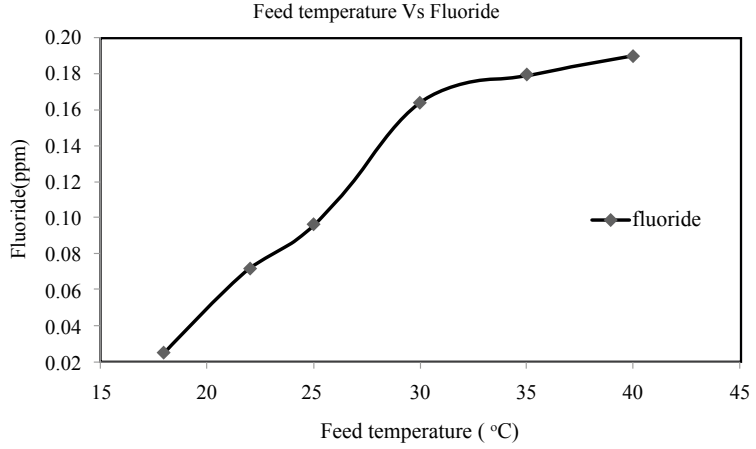

Figure 2: Effect of feed water temperature on permeate salinity (TDS)

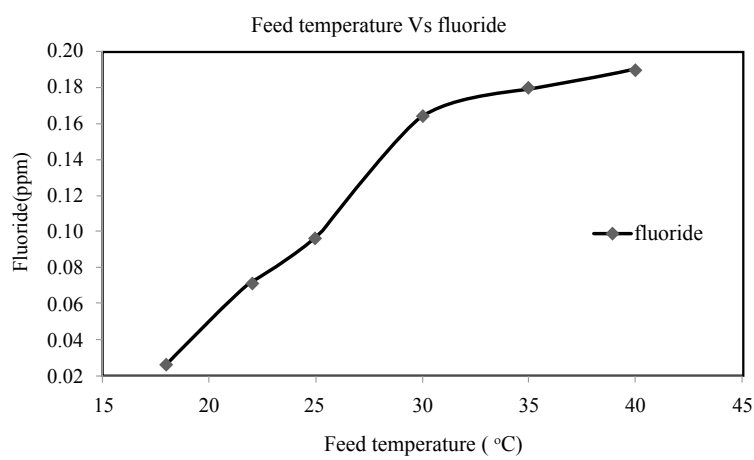

Figure 3: Effect of feed water temperature on \% Salt rejection.

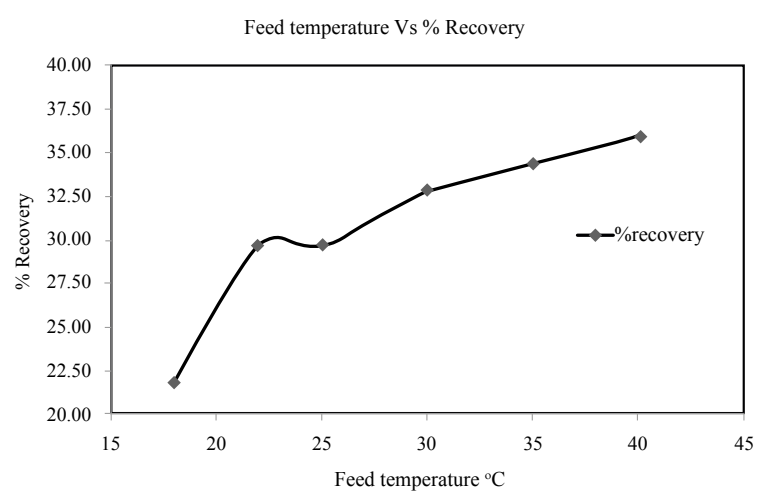

Figure 4: Effect of feed water temperature on permeate flux

which significantly affects the performance of RO membrane. The effect of pressure on the performance of RO membrane was studied by keeping all other parameter constant and the results are shown below graphically. 
Citation: Gedam VV, Patil JL, Kagne S, Sirsam RS, Labhasetwar P (2012) Performance Evaluation of Polyamide Reverse Osmosis Membrane for Removal of Contaminants in Ground Water Collected from Chandrapur District. J Memb Sci Technol 2:117. doi:10.4172/2155-9589.1000117

Based on experimental data, graphs were plotted for pressure verses \% salt rejection, \% recovery, permeate concentration (TDS), and fluoride concentration in permeate. Figure 6-9 shows that, as pressure increases from 30 - 80 psi, \% recovery increases from 13.12 to $48.43 \%$, $\%$ salt rejection increase from 82.5 to 96.5 but fluoride concentration and permeate TDS decreases from 0.778 to $0.0680 \mathrm{ppm}$ and 195 to $31 \mathrm{ppm}$ respectively. Pressure increases the driving force for the solvent and decrease osmotic pressure hence more amount of water can be passed through the membrane with a high rate of salt rejection [8]. From the graph it was observed that, the optimum value of feed pressure for $\mathrm{RO}$ membrane ranges from 70 to $80 \mathrm{psi}$. At this operating pressure, maximum flux and salt rejection was noticed.

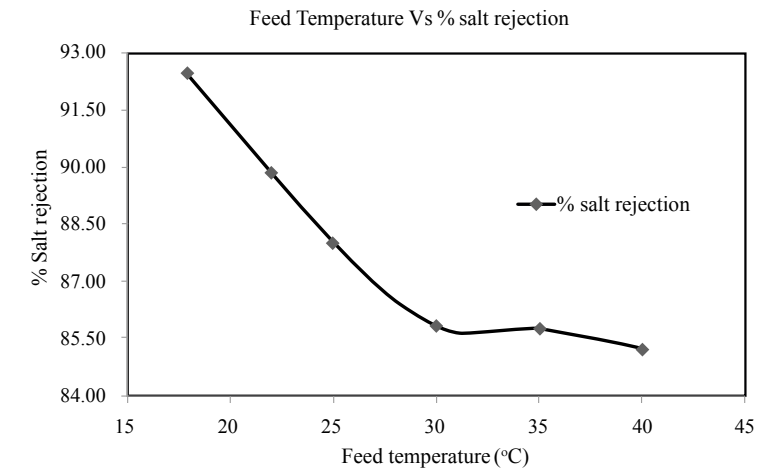

Figure 5: Effect of feed water temperature on the fluoride concentration in permeate water.

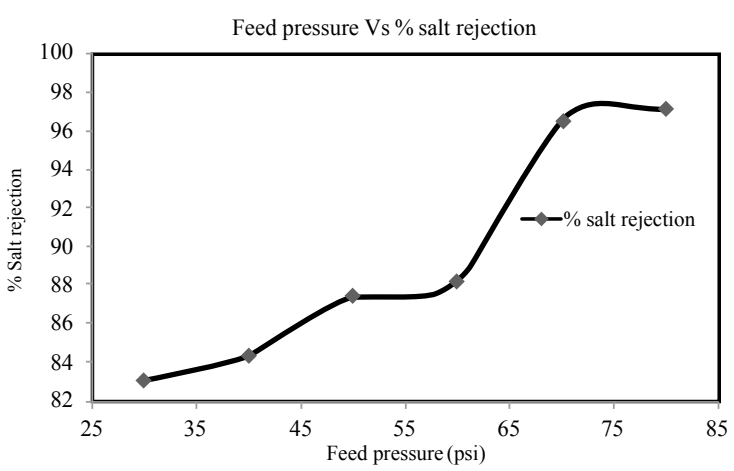

Figure 6: Effect of feed water temperature on \% recovery.

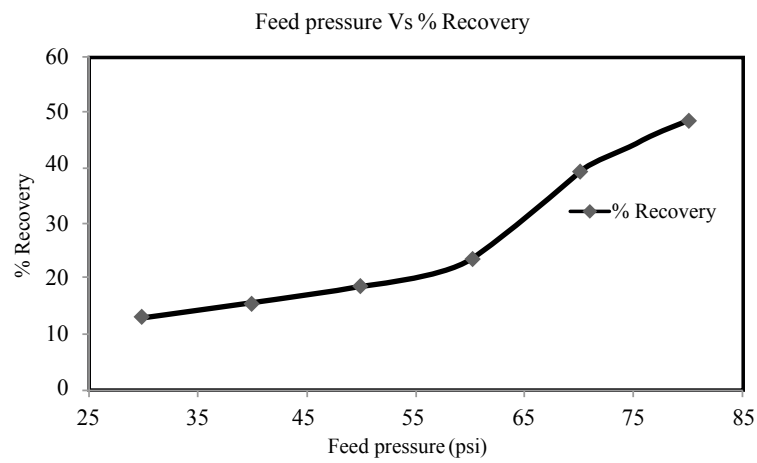

Figure 7: Effect of feed water pressure on permeate salinity (TDS).

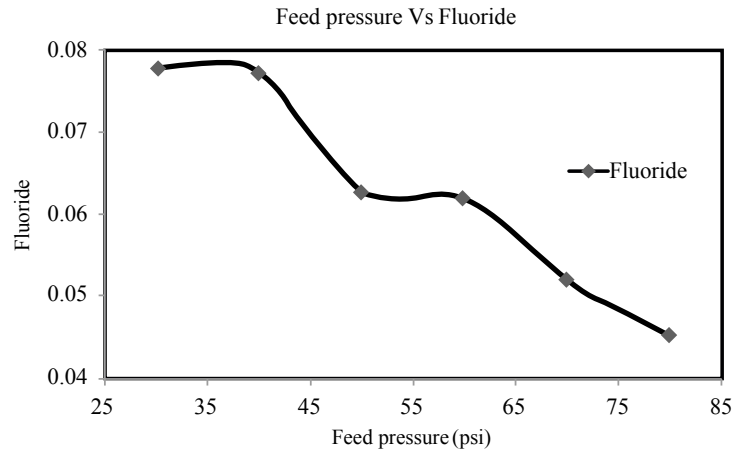

Figure 8: Effect of feed water pressure on concentration of fluoride in permeate water.

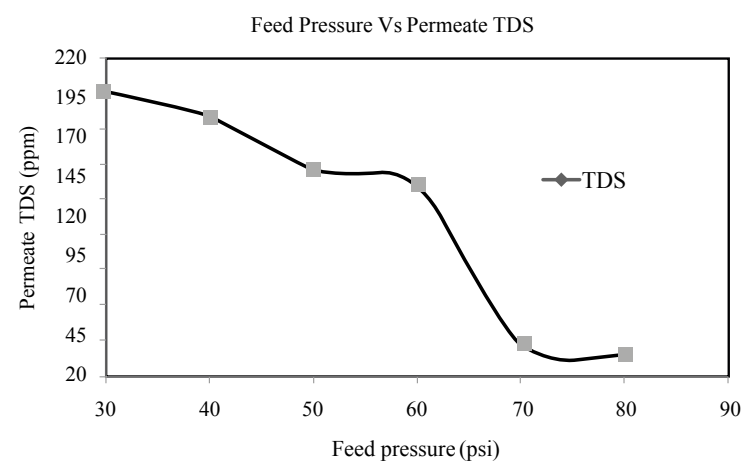

Figure 9: Effect of feed water pressure on permeate salinity.

\begin{tabular}{ll}
\hline Parameter & Membrane permeate \\
\hline Feed pH & 8.06 \\
\hline Feed EC $(\mu \mathrm{S} / \mathrm{cm})$ & 3380 \\
\hline Feed Conc. $-\mathrm{TDS}(\mathrm{ppm})$ & 2010 \\
\hline Temperature $\left({ }^{\circ} \mathrm{C}\right)$ & 22 \\
\hline Vol. of feed water $(\mathrm{L})$ & 5 \\
\hline Chloride $(\mathrm{ppm})$ & 921.7 \\
\hline Fluoride $(\mathrm{ppm})$ & 2.18 \\
\hline Hardness $(\mathrm{ppm})$ & 192 \\
\hline Calcium $(\mathrm{ppm})$ & 152 \\
\hline Magnesium $(\mathrm{ppm})$ & 40 \\
\hline Alkalinity $(\mathrm{ppm})$ & 168 \\
\hline Iron $(\mathrm{ppm})$ & 0.90 \\
\hline Sulphate $(\mathrm{ppm})$ & 145.6 \\
\hline Turbidity NTU & 4.0 \\
\hline
\end{tabular}

Table 3: Physico-chemical Analysis Reject waste water used as feed for RO system.

\section{Effect of feed water $\mathrm{pH}$}

Variation in $\mathrm{pH}$ affects the performance of $\mathrm{RO}$ membrane. Graphs was plotted for feed water $\mathrm{pH}$ verses \% salt rejection, permeate concentration (TDS), \% recovery and fluoride concentration in permeate. Figure 10-13. From Figures 10-13, it was observed that as $\mathrm{pH}$ of the feed water increases \% salt rejection and \% recovery decreases from 91.43 to $89.23 \%$ and 39.06 to $20.31 \%$ respectively while permeate concentration increases from 167 to $210 \mathrm{ppm}$.

$\mathrm{pH}$ affects the separation performance by affecting the hydration 
Citation: Gedam VV, Patil JL, Kagne S, Sirsam RS, Labhasetwar P (2012) Performance Evaluation of Polyamide Reverse Osmosis Membrane for Removal of Contaminants in Ground Water Collected from Chandrapur District. J Memb Sci Technol 2:117. doi:10.4172/2155-9589.1000117

Page 4 of 5

and absorption capacity of solution on membrane [9]. It can be observed from Figure 12 that, as the as $\mathrm{pH}$ increases from 3 to 7 fluoride concentration increases from 0.126 to $0.196 \mathrm{ppm}$ but when $\mathrm{pH}$ further increases from 7 to 9.5 fluoride concentration decreases from 0.195 to $0.123 \mathrm{ppm}$. At acidic $\mathrm{pH}$, the fluoride concentration in permeate decreases because of strong hydrogen bonding of fluoride in acidic solution $[7,10]$.

\section{Recycling potential of reject water}

Household reverse osmosis units use a lot of water because they have low back pressure. As a result, they recover only 5 to 15 percent of the water entering the system. The remainder is discharged as waste

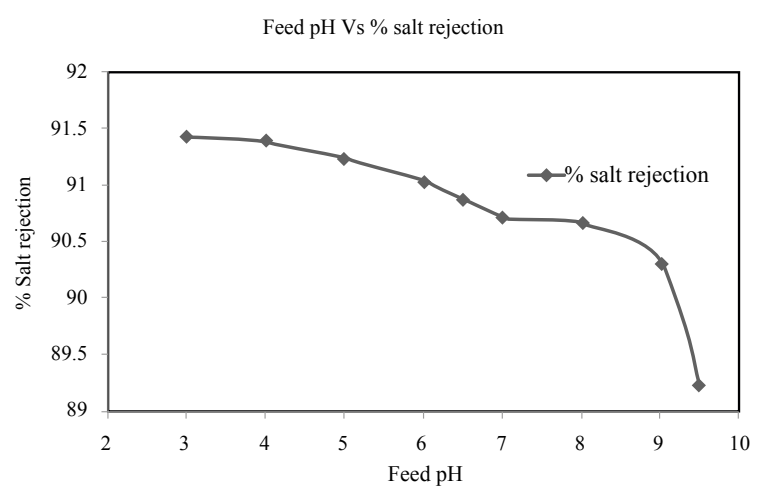

Figure10: Effect of feed water $\mathrm{pH}$ on \% salt rejection.

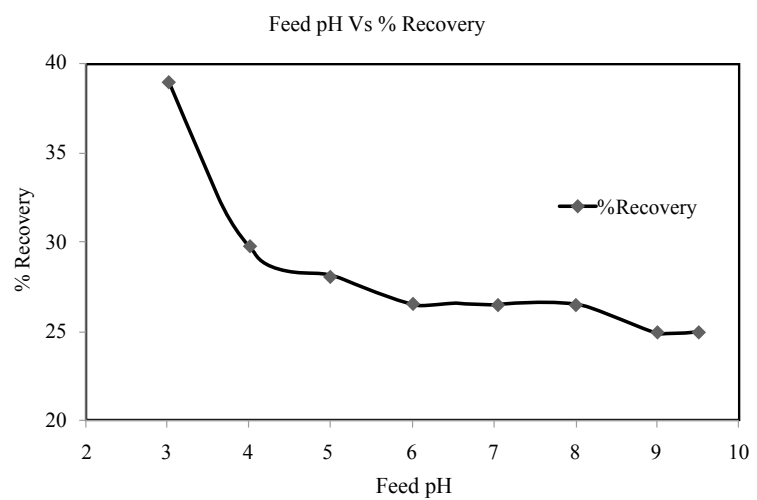

Figure 11: Effect of feed water $\mathrm{pH}$ on \% recovery.

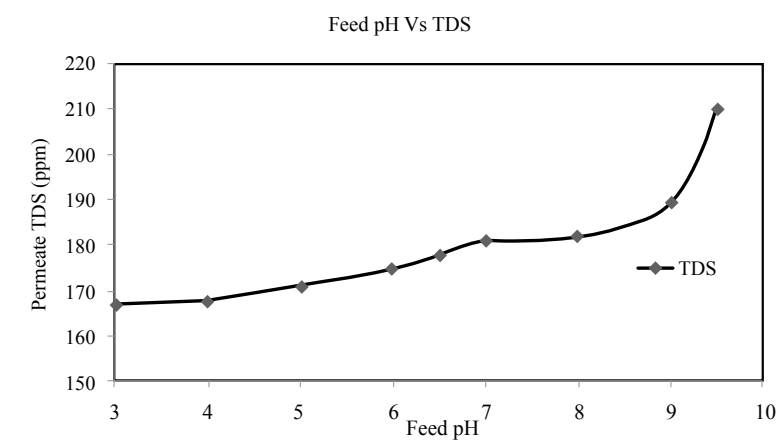

Figure12: Effect of feed water $\mathrm{pH}$ on permeate concentration (TDS) in PPM. water or rejects water which has no further use; this is one of the disadvantages of RO. To study the reuse potential of such enormous amount of reject water; it was recycled through RO module. The Table 3 and Table 4 show the physico-chemical analysis of reject water used as feed for $\mathrm{RO}$ system and recycle reject water after passing from RO membrane.

It can be observed from Table 3 that, during the fifth run of

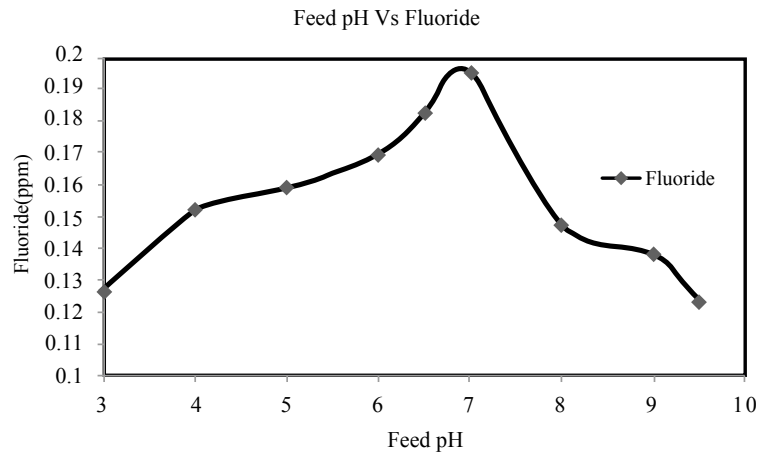

Figure 13: Effect of feed water $\mathrm{pH}$ on concentration of fluoride in permeate water.

\begin{tabular}{|c|c|c|c|c|c|}
\hline Parameter/Concentration & Run-1 & Run-2 & Run-3 & Run-4 & Run-5 \\
\hline \multicolumn{6}{|l|}{ Feed water: } \\
\hline $\mathrm{pH}$ & 8.06 & 8.19 & 8.5 & 8.92 & 7.7 \\
\hline $\mathrm{EC}(\mu \mathrm{S} / \mathrm{cm})$ & 3380 & 3390 & 3720 & 3820 & 3950 \\
\hline Concentration -TDS (ppm) & 2028 & 2034 & 2232 & 2292 & 2370 \\
\hline Volume of water $(\mathrm{L})$ & 5 & 3.9 & 3.1 & 2.54 & 2.35 \\
\hline Temperature $\left({ }^{\circ} \mathrm{C}\right)$ & 22 & 23 & 23 & 23 & 23 \\
\hline \multicolumn{6}{|l|}{ Permeate water: } \\
\hline Flow rate(L/min) & 0.21 & 0.18 & 0.15 & 0.13 & 0.13 \\
\hline Temperature $\left({ }^{\circ} \mathrm{C}\right)$ & 23.7 & 24.1 & 23.3 & 19.1 & 21.7 \\
\hline $\mathrm{pH}$ & 8.5 & 7.29 & 8 & 6.18 & 7.85 \\
\hline $\mathrm{EC}(\mu \mathrm{S} / \mathrm{cm})$ & 150.4 & 311 & 513 & 613 & 819 \\
\hline TDS (ppm) & 90.24 & 186.6 & 307.8 & 367.8 & 491.4 \\
\hline Chloride (ppm) & 36.86 & 65.23 & 106.35 & 141.8 & 170.16 \\
\hline Fluoride (ppm) & 0.044 & 0.0928 & 0.129 & 0.158 & 0.331 \\
\hline Hardness (ppm) & 28 & 24 & 27 & 40 & 48 \\
\hline Calcium (ppm) & 2 & 4 & 8 & 8 & 20 \\
\hline Magnesium (ppm) & 2 & 4 & 4 & 8 & 8 \\
\hline Alkalinity (ppm) & 20 & 16 & 20 & 32 & 40 \\
\hline Iron (ppm) & 0.31 & 0.32 & 0.28 & 0.3 & 0.35 \\
\hline Sulphate (ppm) & 2.38 & 3.21 & 5.11 & 5.35 & 2.94 \\
\hline Turbidity NTU & 0.56 & 0.41 & 0.39 & 0.4 & 0.4 \\
\hline Water collected (lit.) & 1.1 & 0.8 & 0.56 & 0.35 & 0.35 \\
\hline$\%$ salt rejection & 95.51 & 90 & 86.2 & 83.95 & 79.26 \\
\hline \%Recovery & 32.82 & 28.12 & 23.44 & 20.31 & 20.31 \\
\hline Flux (L/m²min) & 2.1 & 1.8 & 1.5 & 1.3 & 1.3 \\
\hline \multicolumn{6}{|l|}{ Membrane permeate: } \\
\hline Flow rate( $(1 / \mathrm{min})$ & 0.57 & 0.56 & 0.56 & 0.56 & 0.57 \\
\hline $\mathrm{EC}(\mu \mathrm{S} / \mathrm{cm})$ & 3390 & 3720 & 3820 & 3950 & 4030 \\
\hline TDS (ppm) & 2034 & 2232 & 2292 & 2370 & 2418 \\
\hline $\mathrm{pH}$ & 8.19 & 8.5 & 8.92 & 7.7 & 7.75 \\
\hline Temperature $\left({ }^{\circ} \mathrm{C}\right)$ & 23.1 & 23 & 23.5 & 20.5 & 23 \\
\hline Water collected (lit.) & 3.9 & 3.1 & 2.54 & 2.35 & 2 \\
\hline
\end{tabular}

Table 4: Physico-chemical analysis of recycle reject water sample for various physico-chemical parameters. 
Citation: Gedam VV, Patil JL, Kagne S, Sirsam RS, Labhasetwar P (2012) Performance Evaluation of Polyamide Reverse Osmosis Membrane for Removal of Contaminants in Ground Water Collected from Chandrapur District. J Memb Sci Technol 2:117. doi:10.4172/2155-9589.1000117

Page 5 of 5

experiment, concentration of permeate water (TDS) increases from 90.24 to $491.4 \mathrm{ppm}$, feed concentration increases from $2010 \mathrm{ppm}$ to $2370 \mathrm{ppm}$, \% salt rejection decreased from $95.51 \%$ to $79.26 \%$, \% recovery decreased from 32.82 to $20.31 \%$ and fluoride concentration increased from 0.044 to $0.331 \mathrm{ppm}$. During the experimental run, reject water through RO membrane was within BIS limit of drinking water (i.e. BIS-10500).

\section{Conclusion}

The RO membrane was very sensitive to various operating parameters such as feed water temperature, pressure and $\mathrm{pH}$. Increase in temperature increases \% recovery, fluoride concentration, permeate concentration (TDS) but decreases the \% salt rejection. Increase in pressure, increases \% recovery, \% salt rejection, but decreases the permeate concentration (TDS) and fluoride concentration. RO is a very efficient process for defluoridation of water as it works at very low pressure and besides fluoride, other inorganic pollutant are also effectively removed. $\mathrm{pH}$ has significant effect on the rejection ratio of fluoride and the observed optimum $\mathrm{pH}$ was 7 . Membrane reject water was recycled through $\mathrm{RO}$ membrane for various runs and experimental data shows that recycling membrane reject water through RO is within BIS (10500) limit of drinking water. From these studies, it may be concluded that polyamide reverse osmosis membrane has potential for membrane reject water recycling but at the same time, feasibility and practicability of reject recycling need to be researched intensively.

\section{References}

1. Gupta S (2012) Drinking Water Quality: A Major Concern in Rural India, Journal of Barnolipi 1: 2249-2666.

2. Grail Research (2009) Water-The India Story.

3. Khurana I, Sen R (2010) Drinking water quality in rural India: issues and approaches, Water Aid India.

4. Central Ground Water Board Ministry Of Water Resources Government O India (2010) Ground Water Quality in Shallow Aquifers of India.

5. Zhao, Shigang, Shi, Weiping (2005) Discussion on Reclaiming and Utilization of Reverse Osmosis Rejected Water. Industrial Water \& Wastewater 36: 58-59.

6. Bureau of Indian standard specification for drinking water BIS: 10500 (1991)

7. Mattheus FA, Sablani SS, Al-Maskari SS, Al-Belushi RH, Wilf M (2002) Effect of feed temperature on permeate flux and mass transfer coefficient in spiralwound reverse osmosis systems. Desalination 144: 367-372.

8. Arora M, Maheshwari RC, Jain SK, Gupta A (2004) Use of membrane technology for potable water production. Desalination 170: 105-112.

9. Berge D, Gad H, Khaled I, Rayan MA (2009) An experimental and analytica study of RO desalination plant. Mansoura Engineering Journal 34: 71-92.

10. Mohammadi T, Moghadam KM, Madaeni SS (2002) Hydrodynamic factors affecting flux and fouling during reverse osmosis of seawater. Desalination 151: $239-245$. 